\title{
ANALISA DOSIS AB MIX TERHADAP NILAI TDS DAN PERTUMBUHAN PAKCOY SECARA HIDROPONIK
}

\author{
Lilik Sulistyowati ${ }^{*}{ }^{(1)}$, Nurhasanah ${ }^{1)}$ \\ 1) Universitas Terbuka, Jakarta, Indonesia \\ *) E-mail Penulis Korespondensi: Liliks@ecampus.ut.ac.id
}

\begin{abstract}
ABSTRAK
Budidaya hidroponik menggunakan larutan $A B$ Mix masih belum banyak digunakan. Budidaya dengan sistem ini menggunakan tanaman pakcoy membutuhkan konsentrasi tertentu agar tanaman dapat tumbuh dengan baik. Penelitian ini bertujuan untuk: 1) menganalisis nilai TDS dalam larutan $A B$ Mix sebelum diencerkan, 2) menganalisis nilai TDS dalam larutan nutrisi, dan 3) menganalisis tinggi tanaman pakcoy yang ditumbuhkan secara hidroponik menggunakan larutan $A B$ Mix. pada dosis yang berbeda. Rancangan percobaan yang digunakan dalam penelitian ini adalah RAL 1 faktor dengan dosis AB Mix 0 ppm, 5 ppm, 10 ppm dan 15 ppm yang berbeda. Variabel yang diamati adalah nilai TDS pada larutan AB Mix sebelum dan sesudah diencerkan serta tinggi tanaman yang ditumbuhkan menggunakan larutan nutrisi dari $A B$ Mix pada 4 dosis yang berbeda. Perlakukan diulang 3 kali. Hasil penelitian menunjukkan larutan AB Mix sebelum diencerkan memiliki nilai TDS sebesar $6763,67 \mathrm{ppm}$. Larutan nutrisi dari AB Mix dengan dosis 15 ppm memiliki nilai tertinggi sebesar 1092,67 ppm dan nilai TDS terendah terdapat pada larutan nutrisi dari AB Mix dengan dosis $5 \mathrm{ppm}$ yaitu $503,67 \mathrm{ppm}$. Sedangkan nilai TDS air yang digunakan sebagai pelarut bahan $A B$ Mix hanya $70 \mathrm{ppm}$. Tinggi tanaman yang diberi larutan AB Mix menunjukkan pola, semakin tinggi dosis $A B$ Mix dari 0 sampai 15 ppm maka tinggi tanaman semakin tinggi.
\end{abstract}

Kata kunci: Hidroponik; Larutan nutrisi; Nilai TDS.

\section{PENDAHULUAN}

Sayuran merupakan salah satu produk pertanian yang banyak dikonsumsi masyarakat pedesaan ataupun perkotaan. Pertambahan penduduk dan peningkatan konsumsi per kapita menyebabkan kebutuhan sayuran juga mengalami peningkatan. Hingga kini konsumsi sayuran penduduk Indonesia masih jauh di bawah standar konsumsi sayur yang direkomendasikan oleh Food and Agriculture Organization (FAO). Salah satu penyebabnya adalah kurangnya pasokan sayuran yang dapat diakses oleh masyarakat.

Salah satu teknologi alternatif yang dapat digunakan untuk pemenuhan kebutuhan sayuran bagi masyarakat Indonesia adalah melalui sistem budidaya dengan cara hidroponik yang dilakukan tanpa menggunakan tanah sebagai media tanamnya. Sayuran yang dihasilkan dari sistem tanam dengan cara ini lebih berkualitas. Salah satu jenis tanaman sayuran yang dapat dibudidayakan dengan cara ini adalah pakcoy (Nugraha dan Susila, 2015).

Pakcoy merupakan kelompok tanaman sayuran yang banyak mengandung zat gizi yang dibutuhkan oleh masyarakat banyak untuk menjaga kesehatan. Pakcoy juga dapat dikonsumsi masyarakat dalam keadaan mentah sebagai lalapan maupun dalam bentuk olahan lainnya (Cahyono, 2003). Produksi pakcoy dengan kualitas serta kuantitas tinggi 
secara kontinyu dapat dilakukan melalui budidaya dengan sistem hidroponik menggunakan larutan nutrisi (Rosliani dan Sumarni, 2005).

Kekurangan salah satu atau beberapa unsur hara dalam tanah umumnya dipenuhi dengan pemupukan tambahan. Semua kebutuhan nutrisi pada budidaya hidroponik diupayakan tersedia dalam jumlah yang tepat dan mudah diserap oleh tanaman. Pemberian nutrisi melalui pemupukan media tanam atau akar tanaman. Nutrisi yang diberikan dalam bentuk larutan yang berasal dari bahan organik dan anorganik yang mengandung nutrisi hara makro dan mikro (Sina \& Nurjani, 2018).

Pertumbuhan dan perkembangan tanaman terutama unsur hara nitrogen untuk tanaman pakchoy. Unsur nitrogen yang rendah pada perlakuan POC $125 \mathrm{ml} / \mathrm{L}$ air (A) mengakibatkan terhambatnya pertumbuhan dan perkembangan tanaman, seperti yang dikemukakan oleh Gardner at. all. (1991), fungsi esensial dari unsur hara nitrogen didalam jaringan tanaman adalah pembelahan dan pembesaran sel-selnya akan mengalami hambatan. Rendahnya penyerapan unsur hara mempengaruhi laju fotosintesis dan juga kandungan protein sehingga perkembangan tanaman menjadi terhambat yang mengakibatkan rendahnya hasil bobot segar tanaman.

Larutan nutrisi adalah larutan yang berisi zat-zat yang dibutuhkan tanaman. Larutan nutrisi yang umum digunakan dalam sistem budidaya tanaman dengan cara hidroponik adalah pupuk padat yang dinamakan $A B$ mix yang nantinya dilarutkan dengan sejumlah air sesuai dengan yang direkomendasikan oleh produsennya. Secara umum, pupuk $A B$ mix mengandung hara makro dan hara mikro yang dibutuhkan tanaman. Menurut Harjowigeno (2010), hara makro N, P, K, Ca, Mg, S dan hara mikro $\mathrm{Cu}, \mathrm{Mn}, \mathrm{Zn}, \mathrm{Fe}$ dibutuhkan tanaman untuk proses metabolisme agar tanaman dapat tumbuh dan berkembang.

Konsentrasi larutan nutrisi yang digunakan dalam budidaya dengan sistem hidroponik merupakan salah satu faktor yang harus diperhatikan. Hal ini karena setiap jenis tanaman memerlukan tingkatan konsentrasi hara yang berbeda. Konsentrasi larutan nutrisi menunjukkan kepekatan zat-zat yang ada di dalamnya. Larutan nutrisi dengan kepekatan terlalu rendah ataupun terlalu tinggi dapat menghambat pertumbuhan tanaman (Roan, 1998).

Hingga kini belum tersedia rekomendasi konsentrasi larutan hara yang optimum untuk budidaya pakcoy. Tujuan dari penelitian ini adalah: 1) menganalisis nilai TDS pada larutan AB Mix sebelum diencerkan; 2) Menganalisis nilai TDS pada larutan nutrisi; dan 3) Menganalisis tinggi tanaman pakcoy yang ditanam secara hidroponik menggunakan larutan AB Mix pada dosis yang berbeda.

\section{METODE}

\section{Tahapan Penelitian}

Penelitian ini merupakan penelitian eksperimental. Penelitian ini dilakukan dari bulan Agustus sampai Nopember 2019 yang dilaksanakan di Tangerang, Pondok Cabe dalam beberapa tahap, yakni: diawali dengan pembuatan pupuk cair dari $A B$ Mix sebagai sumber larutan nutrisi, kemudian dilakukan pembibitan benih pakcoy yang sudah dipilih sebelumnya, Penyiapan alat yang digunakan untuk budidaya hidroponik dan pembuatan larutan nutrisi dari AB Mix pada 4 dosis yang berbeda $(0 \mathrm{ppm}, 5 \mathrm{ppm}$, $10 \mathrm{ppm}$ dan $15 \mathrm{ppm}$ ). Setlah dilakukan larutan nutrisi maka pada budidaya pakcoy dengan sistem hidroponik menggunakan larutan nutrisi dari $A B$ Mix pada 4 dosis $(0$ ppm, 5 ppm, 10 ppm dan 15 ppm), Serta pengukuran nilai TDS pada larutan AB Mix sebelum dan sesudah diencerkan, maka pengukuran tinggi tanaman pakcoy yang ditanam secara hidroponik menggunakan larutan nutrisi dari bahan $A B$ Mix pada 4 dosis yang berbeda. 


\section{Pengumpulan Data}

Data yang dikumpulkan dalam penelitian ini adalah data primer yang diperoleh dari hasil eksperimen. Data tersebut terdiri dari data pada nilai TDS dari larutan AB Mix sebelum diencerkan kemudian data nilai TDS dari larutan AB Mix setelah diencerkan menjadi larutan nutrisi, serta data tinggi tanaman pada pakcoy yang ditanam menggunakan larutan nutrisi dari AB Mix pada 4 dosis yang berbeda.

\section{Rancangan Percobaan}

Rancangan percobaan yang digunakan adalah Rancangan Acak Lengkap (RAL) 1 faktor dengan 4 perlakuan (dosis AB Mix), yakni: 0 ppm, 5 ppm, 10 ppm dan 15 ppm. Masing-masing perlakuan diulang 3 kali sehingga jumlah satuan percobaan ada 12 . Variabel yang diamati adalah nilai TDS dan tinggi tanaman pakcoy.

\section{Pengolahan Data dan Analisis Data}

Data yang didapat dari hasil penelitian ini, berupa: nilai TDS, $\mathrm{pH}$ dan tinggi tanaman. Pada larutan AB Mix dan pupuk organik cair dari bahan air kelapa, bawang merah, jagung dan tauge sebelum diencerkan menjadi larutan nutrisi, variabel yang diamati adalah nilai TDS dan $\mathrm{pH}$. Rancangan percobaan yang digunakan pada tahap ini adalah Rancangan Acak Lengkap (RAL) 1 faktor dengan 5 (lima) perlakuan yakni:

$A B \quad: A B$ mix

AK : Pupuk organik cair berbahan dasar air kelapa

BM : Pupuk organik cair berbahan dasar bawang merah

$\mathrm{J} \quad$ : Pupuk organik cair berbahan dasar jagung

$\mathrm{T} \quad$ : Pupuk organik cair berbahan dasar tauge

Masing-masing perlakuan diulang 3 kali sehingga jumlah satuan percobaan adalah sebanyak 15 kali.

Tabel 1. Kode Dari Masing-Masing Perlakuan

\begin{tabular}{|c|c|c|c|c|c|}
\hline \multicolumn{2}{|c|}{ Tambahan Nutrisi } & \multicolumn{4}{|c|}{ Dosis AB Mix (AB) } \\
\hline $\begin{array}{l}\text { Sumber } \\
\text { Nutrisi }\end{array}$ & Dosis & $0 \mathrm{ppm}$ & 5 ppm & 10 ppm & 15 ppm \\
\hline \multirow{3}{*}{ Air kelapa (AK) } & $20 \mathrm{ml} / \mathrm{l}$ & AK20AB0 & AK20AB5 & AK20AB10 & AK20AB15 \\
\hline & $30 \mathrm{ml} / \mathrm{l}$ & AK30AB0 & AK30AB5 & AK30AB10 & AK30AB15 \\
\hline & $40 \mathrm{ml} / \mathrm{l}$ & AK40AB0 & AK40AB5 & AK40AB10 & AK40AB15 \\
\hline \multirow{3}{*}{ Jagung (J) } & $20 \mathrm{ml} / \mathrm{l}$ & J20AB0 & J20AB5 & J20AB10 & J20AB15 \\
\hline & $30 \mathrm{ml} / \mathrm{l}$ & J30AB0 & J30AB5 & J30AB10 & J30AB15 \\
\hline & $40 \mathrm{ml} / \mathrm{l}$ & J40AB0 & J40AB5 & J40AB10 & J40AB15 \\
\hline \multirow{3}{*}{ Tauge $(T)$} & $20 \mathrm{ml} / \mathrm{l}$ & T20AB0 & T20AB5 & T20AB10 & T20AB15 \\
\hline & $30 \mathrm{ml} / \mathrm{l}$ & T30AB0 & T30AB5 & T30AB10 & T30AB15 \\
\hline & $40 \mathrm{ml} / \mathrm{l}$ & T40AB0 & T40AB5 & T40AB10 & T40AB15 \\
\hline \multirow{3}{*}{$\begin{array}{l}\text { Bawang merah } \\
\text { (BM) }\end{array}$} & $20 \mathrm{ml} / \mathrm{l}$ & BM20AB0 & BM20AB5 & BM20AB10 & BM20AB15 \\
\hline & $30 \mathrm{ml} / \mathrm{l}$ & ВМЗОАВ0 & BM30AB5 & ВM30AB10 & BM30AB15 \\
\hline & $40 \mathrm{ml} / \mathrm{l}$ & BM40AB0 & BM40AB5 & BM40AB10 & BM40AB15 \\
\hline
\end{tabular}

Sumber: Data diolah penulis, 2019 
Pada larutan nutrisi yang dibuat dari larutan AB Mix dan pupuk organik cair dari bahan air kelapa, bawang merah, jagung dan tauge dengan cara pengeceran yakni: 4 dosis AB Mix (0 ppm, 5 ppm, 10 ppm dan 15 ppm) dan 3 dosis dari pupuk organik cair dari bahan air kelapa, bawang merah, jagung dan tauge $(20$ ppm, 30 ppm dan 40 ppm). Variabel yang diamati adalah nilai TDS dan $\mathrm{pH}$.

Variabel yang diamati adalah tinggi tanaman pak coy. Rancangan percobaan yang digunakan pada tahap ini adalah RAL 2 faktor. Faktor 1 dengan 4 perlakuan dosis $A B$ mix (0 ppm, 5 ppm, 10 ppm dan 15 ppm) dan faktor 2 dengan 3 perlakuan dosis pupuk organik cair dari bahan yang berbeda (air kelapa, bawang merah, jagung dan tauge).

Jumlah perlakuan ada 4 (dosis AB Mix) $\times 4$ (jenis pupuk organik cair) $\times 3$ (dosis pupuk organik cair) $=48$. Masing-masing perlakuan diulang 3 kali sehingga jumlah satuan percobaan ada 144. Kode dari perlakuan ini sama seperti yang ada pada Tabel 2. Selain itu, ada perlakuan tambahan yakni: larutan nutrisi yang diberi perlakuan $A B$ mix saja dengan dosis 0 ppm, 5 ppm, 10 ppm dan 15 ppm. Data yang didapat dari hasil penelitian ini, berupa: nilai TDS, $\mathrm{pH}$ dan tinggi tanaman. Data ini diuji dengan menggunakan tehnik statistik Anova dengan uji lanjut Duncan.

\section{HASIL DAN PEMBAHASAN}

Larutan $\mathrm{AB}$ Mix berisi sumber hara baik hara makro maupun hara mikro yang dibutuhkan tanaman. Dosis atau kepekatan dari larutan AB Mix yang digunakan sebagai larutan nutrisi tidak boleh melebihi dari batas yang dapat ditoleransi oleh tanaman. Oleh karenanya, larutan AB Mix ini diencerkan agar dosisnya masih dapat ditoleransi tanaman.

Pupuk $A B$ mix yang digunakan untuk budidaya sayuran melalui cara hidroponik yang dipanen daunnya terdiri dari pupuk jenis $A$ dan jenis $B$. Pupuk jenis $A$ mengandung Kalsium nitrat 1176 gram, Kalium nitrat 616 gram dan Fe EDTA 38 gram. Sedangkan pupuk jenis B mengandung Kalium dihidro fosfat 335 gram, Amnonium sulfat 122 gram, Kalium sulfat 36 gram, Magnesium sulfat 790, Cupri sulfat 0,4 gram, Zinc sulfat 1,5 gram, Asam borat 4,0 gram, Mangan Sulfat 8 gram, dan Amonium hepta molibdat 0,1 gram (Sastro dan Rokhmah, 2016). Hasil penelitian Wulan dan Susila (2018) menunjukkan bahwa larutan $\mathrm{AB}$ mix mengandung $\mathrm{NH} 4+22.5 \mathrm{ppm}, \mathrm{K}+429$ ppm, Ca2+ 180 ppm, Mg2+ 24 ppm, NO3- 1178 ppm, SO42- 108 ppm, H2PO4- 194 ppm, Fe3+ 2.232 ppm, Mn3+ 0.275 ppm, Zn2+ 0.261 ppm, B3+ 0.324 ppm, Cu2+ 0.049 ppm dan Mo2+ 0.048 ppm.

Secara umum, pupuk $A B$ mix mengandung hara makro dan hara mikro yang dibutuhkan tanaman. Menurut Harjowigeno (2010), hara makro N, P, K, Ca, Mg, S dan hara mikro $\mathrm{Cu}, \mathrm{Mn}, \mathrm{Zn}$, Fe dibutuhkan tanaman untuk proses metabolisme agar tanaman dapat tumbuh dan berkembang.

Nilai TDS dapat menjadi indikator kepekatan dari larutan nutrisi. Larutan nutrisi dengan nilai TDS yang tinggi berarti larutan nutrisi lebih pekat dibanding larutan nutrisi dengan nilai TDS yang rendah. Larutan nutrisi yang pekat merupakan indikator konsentrasi hara yang ada di dalamnya lebih pekat.

Atas dasar hal tersebut di atas, maka nilai TDS dapat dijadikan indikator layak atau tidak larutan nutrisi dalam mendukung pertumbuhan tanaman. Salah satu indikator pertumbuhan tanaman adalah tinggi tanaman. Hasil penelitian menunjukkan nilai TDS pada larutan nutrisi yang dibuat dari AB Mix dengan atau tanpa pengenceran menunjukkan nilai yang bervariasi. Berikut adalah hasil penelitian tersebut. Menurut Sarido dan Junia (2017) perbedaan pada pemberian pupuk organik cair Nasa ini ditunjukkan pada rata rata lebar daun pakcoy pada umur 20 HST serta rata-rata berat basah tanaman pakcoy setelah panen. kemudian konsentrasi pupuk organik cair Nasa 
yang terbaik adalah konsentrasi $6 \mathrm{cc}$ / liter air (P3) dengan jumlah daun 11,09 helai dan berat basah 60,58 gram.

Gambar 1 menunjukkan nilai TDS dari larutan nutrisi yang dibuat dari larutan $A B$ Mix dengan atau tanpa pengenceran berkisar antara 503,67 ppm sampai 6763,67 ppm. Hal ini menunjukkan terjadi peningkatan bahan terlarut yang ada di dalam larutan nutrisi. Nilai TDS mengalami peningkatan dengan makin meningkatnya dosis $A B$ Mix yang digunakan, yakni 503,67 ppm pada larutan nutrisi yang dibuat dari $A B$ Mix dengan dosis 5 ppm, 875,00 ppm pada larutan nutrisi yang dibuat dari AB Mix dengan dosis 10 ppm, dan 1092,67 ppm pada larutan nutrisi yang dibuat dari AB Mix dengan dosis $15 \mathrm{ppm}$.

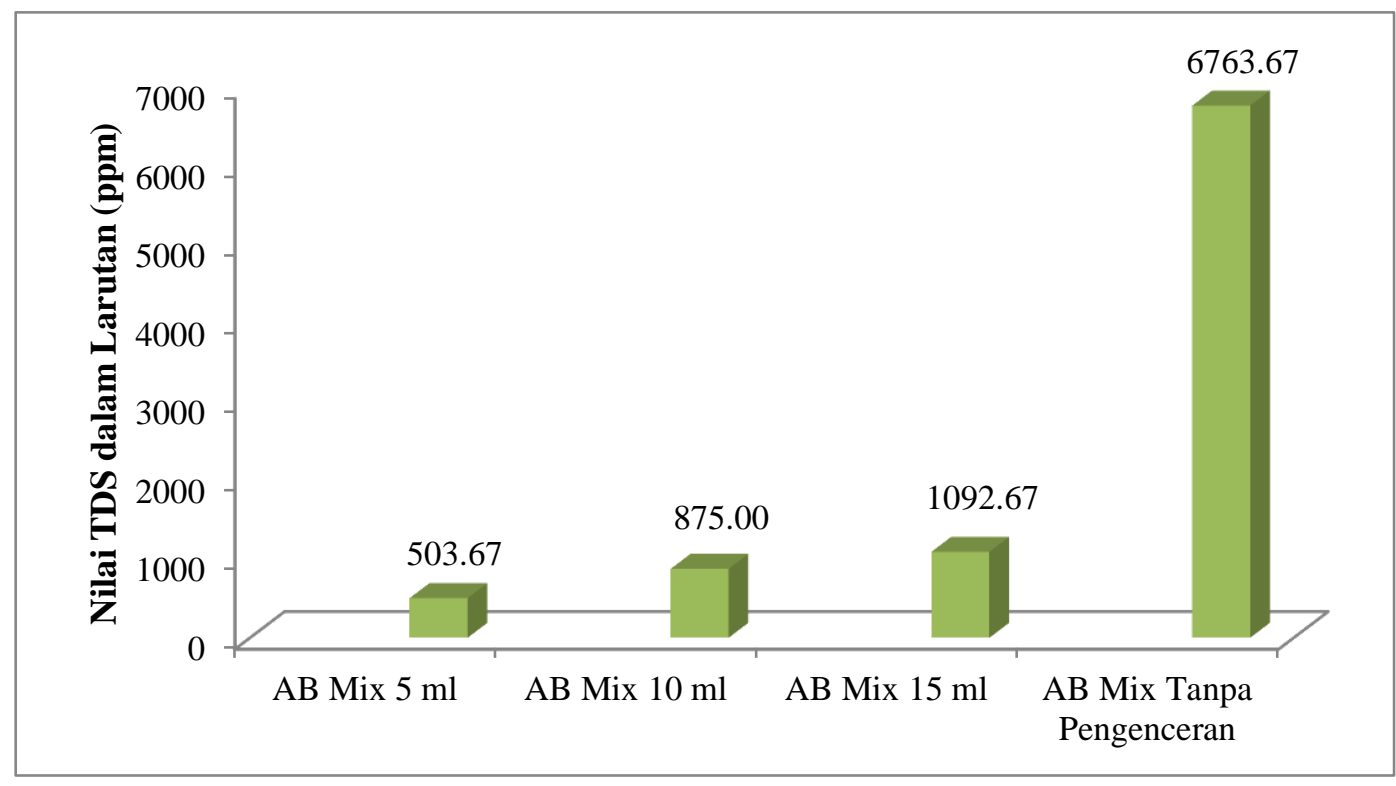

Gambar 1. Nilai TDS pada Larutan Nutrisi yang dibuat dari AB Mix dengan atau Tanpa Pengenceran

Sumber: Data primer diolah, 2019

\section{Tinggi Tanaman Pakcoy yang Ditanam secara Hidroponik}

Tinggi tanaman yang ditanam secara hidroponik merupakan indikator kemanfaatan penggunaan larutan nutrisi dalam menunjang pertumbuhan tanaman. Data tinggi tanaman yang diperoleh dari hasil penelitian ini seperti ditunjukkan pada Gambar 2.

Pada Gambar 2 menunjukkan pola, semakin tinggi dosis AB Mix yang ada pada larutan nutrisi (mulai dari 0 ppm hingga 15 ppm) menyebabkan tinggi tanaman menjadi semakin tinggi. Tinggi tanaman tertinggi terdapat pada tanaman yang diberi larutan nutrisi $A B$ Mix $15 \mathrm{ppm}$, dan tinggi tanaman terendah terdapat pada tanaman yang diberi larutan nutrisi tanpa AB Mix.

Tinggi yang dicapai tanaman yang ditanam secara hidroponik berkaitan dengan kecukupan hara yang ada di larutan nutrisi. Tanaman yang ditanam menggunakan larutan nutrisi 15 ppm diduga mengandung kadar hara makro maupun hara mikro yang dibutuhkan tanaman lebih tinggi dibanding kadar hara makro dan hara mikro yang ada di larutan nutrisi yang mengandung $\mathrm{AB}$ Mix dengan konsentrasi yang lebih rendah (10 ppm, 5 ppm maupun 0 ppm). Berikut adalah hasil uji statistik terhadap tinggi tanaman yang ditanam secara hidroponik menggunakan larutan nutrisi $A B$ Mix pada dosis yang berbeda. 


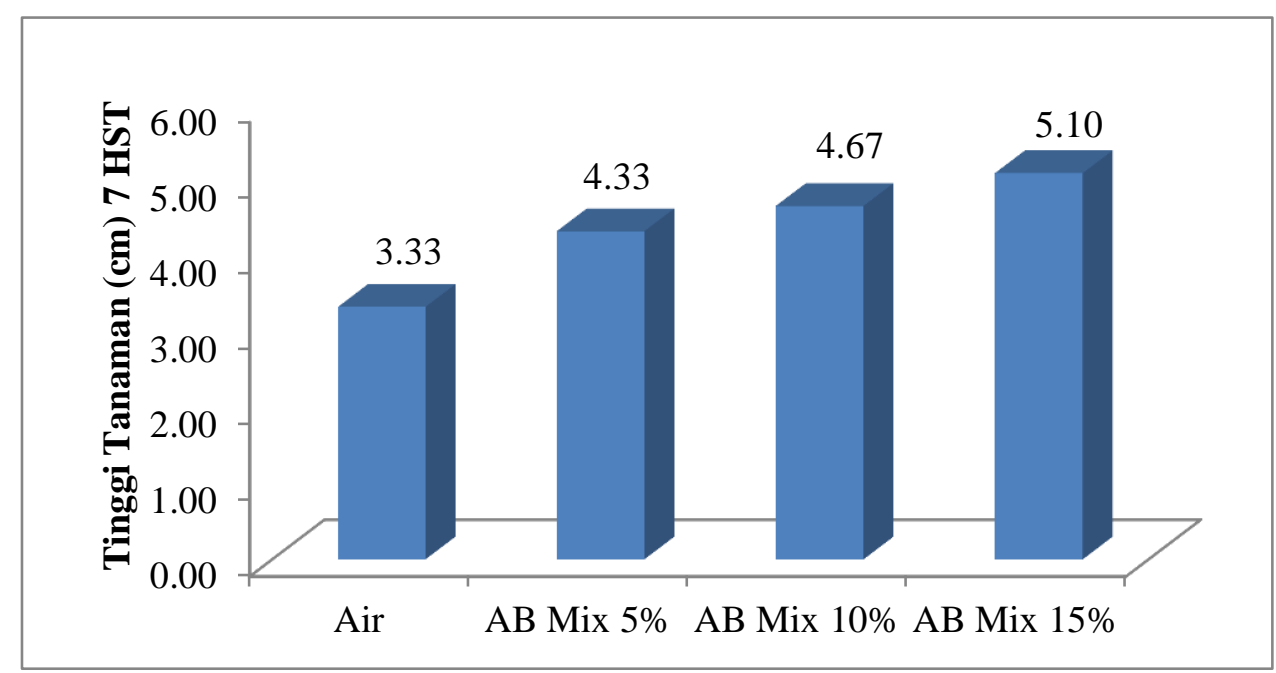

Gambar 2. Tinggi Tanaman Pakcoy 7 HST

Sumber: Data primer diolah, 2019

Tabel 2. Hasil Uji Statistik Tinggi Tanaman yang ditanam Secara Hidroponik Menggunakan Larutan Nutrisi dari AB Mix

\begin{tabular}{clc}
\hline No. & \multicolumn{1}{c}{ Jenis Larutan Nutrisi } & Nilai TDS \\
\hline 1. & Air & $3,33 \mathrm{a}$ \\
2. & AB Mix $5 \mathrm{ml}$ & $4,33 \mathrm{~b}$ \\
3. & AB Mix $10 \mathrm{ml}$ & $4,67 \mathrm{~b}$ \\
4. & AB Mix $15 \mathrm{ml}$ & $5,10 \mathrm{~b}$ \\
\hline
\end{tabular}

Catatan: Angka yang diikuti huruf yang berbeda, berbeda secara signifikan pada taraf 5\%. Sumber: Data primer diolah, 2019

Pada Tabel 2 menunjukkan bahwa berdasarkan hasil uji statistik, penggunaan larutan nutrisi dari $\mathrm{AB}$ Mix menyebabkan tinggi tanaman lebih tinggi dan berbeda nyata dibanding kontrol (air saja). Namun demikian, tinggi tanaman yang diberi larutan nutrisi $A B$ Mix baik pada dosis 5 ppm, 10 ppm dan 15 ppm meskipun mengalami peningkatan, namun secara statistik belum menunjukkan perbedaan yang signifikan.

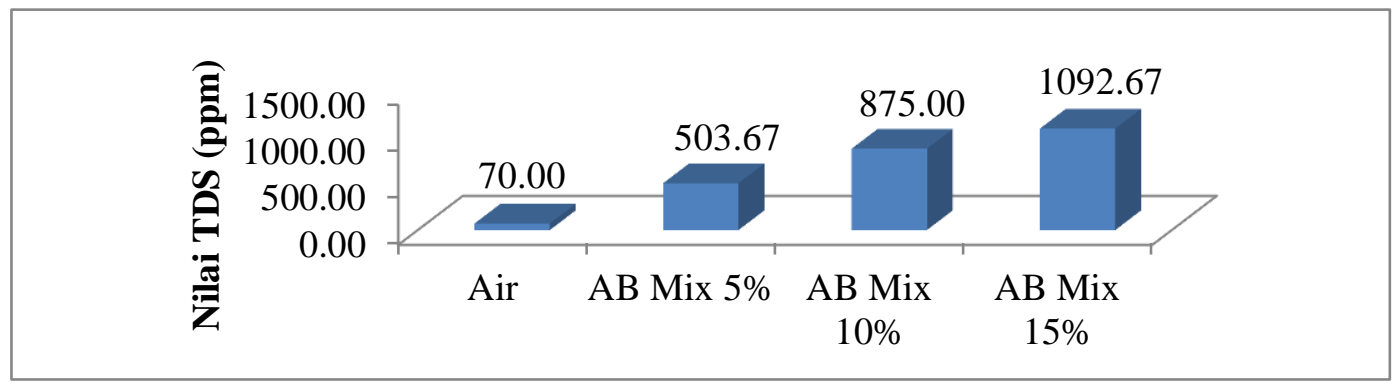

Gambar 3. Nilai TDS pada Larutan Nutrisi dari AB Mix Sumber: Data primer diolah, 2019

Tinggi tanaman yang semakin tinggi dengan semakin tinggi dosis $A B$ Mix ini berkaitan dengan kadar hara yang semakin tinggi yang terdapat pada dosis $A B$ Mix yang semakin tinggi. Hal ini menyebabkan kebutuhan hara oleh tanaman yang ditanam secara hidroponik menjadi lebih terpenuhi. Indikator dari keberadaan hara di dalam 
larutan nutrisi yang berasal dari larutan $A B$ Mix ditunjukkan oleh nilai TDS yang semakin tinggi dengan semakin tinggi dosis larutan AB Mix yang ada di larutan nutrisi. Semakin tinggi nilai TDS menunjukkan bahwa di dalam larutan nutrisi mengandung bahan terlarut yang semakin tinggi. Bahan terlarut tersebut terdiri dari hara makro dan hara mikro. Berikut adalah nilai TDS dari larutan nutrisi yang dibuat dari larutan AB Mix pada dosis yang berbeda.

Gambar 3 menunjukkan nilai TDS tertinggi sebesar 1092,67 ppm terdapat pada larutan nutrisi dari penggunaan AB Mix $15 \mathrm{ml}$ dan nilai TDS terendah sebesar 503,67 ppm terdapat pada larutan nutrisi dari penggunaan AB Mix $5 \mathrm{ml}$. Sementara pada perlakuan kontrol (larutan nutrisi dari air aqua) memiliki nilai TDS hanya 70 ppm. Berikut adalah hasil uji statistik terhadap nilai TDS pada larutan nutrisi yang diberi $A B$ Mix pada dosis yang berbeda.

Tabel 3. Nilai TDS Pada Larutan Nutrisi Dari AB Mix

\begin{tabular}{clc}
\hline No. & \multicolumn{1}{c}{ Jenis Larutan Nutrisi } & Nilai TDS (ppm) \\
\hline 1. & Air aqua (kontrol) & $70,00 \mathrm{a}$ \\
2. & AB Mix $5 \mathrm{ml}$ & $503,67 \mathrm{~b}$ \\
3. & AB Mix $10 \mathrm{ml}$ & $875,00 \mathrm{c}$ \\
4. & AB Mix $15 \mathrm{ml}$ & $1092,67 \mathrm{~d}$ \\
\hline
\end{tabular}

Catatan: Angka yang diikuti huruf yang berbeda, berbeda secara signifikan pada taraf $1 \%$.

Sumber: Data primer diolah, 2019

Berdasarkan hasil uji statistik, nilai TDS dari keempat perlakuan saling berbeda nyata pada taraf $1 \%$ (Tabel 3). Larutan nutrisi dengan nilai TDS yang lebih tinggi mengandung hara yang lebih tinggi pula dibanding hara yang terdapat pada larutan nutrisi dengan nilai TDS yang lebih rendah. Hasil penelitian Syariefa (2015), kisaran kandungan hara yang terdapat pada larutan AB Mix sebagai berikut.

Tabel 4. Kisaran Kandungan Nutrisi Pada Pupuk Cair AB Mix Hidroponik

\begin{tabular}{|c|c|c|c|}
\hline No & Elemen & $\begin{array}{c}\text { Bentuk ion yang diserap } \\
\text { tanaman }\end{array}$ & $\begin{array}{l}\text { Batasan umum } \\
\text { (ppm = mg/l) }\end{array}$ \\
\hline 1. & Nitrogen & NO3-. NH4+ & $100-250$ \\
\hline 2. & Fosfor & H2PO4-, PO43-, HPO42 & $30-50$ \\
\hline 3. & Potasium & $\mathrm{K}_{+}$ & $100-300$ \\
\hline 4. & Kalsium & $\mathrm{Ca} 2+$ & $80-140$ \\
\hline 5. & Magnesium & $\mathrm{Mg} 2+$ & $30-70$ \\
\hline 6. & Sulfur & SO42- & $50-120$ \\
\hline 7. & Besi & $\mathrm{Fe} 2+, \mathrm{Fe} 3+$ & $1,0-3,0$ \\
\hline 8. & Tembaga & $\mathrm{Cu} 2+$ & $0,08-0,2$ \\
\hline 9. & Mangan & $\mathrm{Mn} 2+$ & $0,5-1,0$ \\
\hline 10. & Zink & $\mathrm{Zn} 2+$ & $0,3-0,6$ \\
\hline 11. & Molibdenum & Mo042- & $0,04-0,08$ \\
\hline 12. & Boron & BO32-, B4O72- & $0,2-0,5$ \\
\hline 13. & Klorida & $\mathrm{Cl}-$ & $<75$ \\
\hline 14. & Sodium & $\mathrm{Na}$ & $>50$ \\
\hline
\end{tabular}

Sumber: Syariefa, 2015

Tabel 4 Kisaran kandungan nutrisi pada pupuk cair $A B$ Mix hidroponik menunjukkan larutan nutrisi dari $A B$ Mix mengandung hara makro dan hara mikro. Kadar hara yang tertinggi adalak $\mathrm{K}+$ dan kadar hara yang terendah adalah $\mathrm{Mo}$. $\mathrm{pH}$ baik 
pada air yang digunakan sebagai bahan pelarut $A B$ Mix maupun $\mathrm{pH}$ pada larutan nutrisi yang sudah jadi menggunakan $A B$ Mix pada dosis $5 \mathrm{ml}, 10 \mathrm{ml}$ dan $15 \mathrm{ml}$ yang dilarutkan pada 1 liter air, menunjukkan $\mathrm{pH}$ yang bervariasi. Hasil penelitian tersebut sebagai berikut.

Tabel 5. Hasil Uji Statistik

\begin{tabular}{clc}
\hline No. & \multicolumn{1}{c}{ Jenis Larutan Nutrisi } & Nilai TDS (ppm) \\
\hline 1. & Air & $7,20 \mathrm{a}$ \\
2. & AB Mix $5 \mathrm{ml}$ & $6,67 \mathrm{~b}$ \\
3. & AB Mix $10 \mathrm{ml}$ & $6,20 \mathrm{c}$ \\
4. & AB Mix $15 \mathrm{ml}$ & $6,03 \mathrm{c}$ \\
\hline
\end{tabular}

Catatan: Angka yang diikuti huruf yang berbeda, berbeda secara signifikan pada taraf $1 \%$.

Sumber: Data primer diolah, 2019

Berdasarkan hasil uji statistik menunjukkan $\mathrm{pH}$ dari keempat pelakuan berbeda nyata pada taraf $1 \%$ (Tabel 8 ). $\mathrm{pH}$ tertinggi terdapat pada air yang dijadikan pelarut yakni sebesar 7,20 yang nilainya berbeda nyata dibanding $\mathrm{pH}$ larutan nutrisi dari larutan $A B$ Mix baik pada dosis $5 \mathrm{ml}, 10 \mathrm{ml}$ atau $15 \mathrm{ml}$ yang dilarutkan dengan menggunakan 1 liter air. Sedangkan $\mathrm{pH}$ pada larutan nutrisi yang dibuat dari larutan $A B$ Mix dengan dosis $10 \mathrm{ml}$ dan $15 \mathrm{ml}$ tidak berbeda nyata. Hal ini sekaligus menunjukkan bahwa bahan padat pada $A B$ Mix yang digunakan untuk membuat larutan nutrisi bersifat masam sehingga terjadi penurunan $\mathrm{pH}$ setelah bahan padat tersebut dicampur dengan air. Pernyataan ini sama dengan penelitian yang dilakukan Telaumbanua (2020) bahwa interaksi antara pemberian pupuk organik cair buah pepaya dan pupuk $A B$ Mix pada berbagai perlakuan konsentrasi berpengaruh tidak nyata terhadap tinggi tanaman, jumlah daun, panjang akar, bobot basah panen total dan bobot jual tanaman pakcoy.

\section{SIMPULAN}

Larutan AB Mix sebelum diencerkan memiliki nilai TDS sebesar 6763,67 ppm, Larutan nutrisi dari AB Mix dengan dosis 15 ppm memiliki nilai tertinggi 1092,67 ppm dan nilai TDS terendah terdapat pada larutan nutrisi dari AB Mix dengan dosis $5 \mathrm{ppm}$ yakni sebesar 503,67 ppm. Sementara nilai TDS dari air yang digunakan sebagai pelarut bahan $A B$ Mix hanya sebesar 70 ppm, Tinggi tanaman yang diberi larutan $A B$ Mix menunjukkan pola, semakin tinggi dosis $A B$ Mix dari 0 sampai 15 ppm menyebabkan tinggi tanaman semakin tinggi.

\section{DAFTAR PUSTAKA}

Cahyono, B. (2003). Teknik dan Strategi Budidaya Sawi Hijau (Pai-Tsai). Yayasan Pustaka Nusatama: Yogyakarta.

Harjowigeno, S. (2010). IImu Tanah. Jakarta: Mediyatama Sarana Perkasa.

Nugraha, R. U. dan Susila, A. D. (2015). Sumber Sebagai Hara Pengganti AB mix pada Budidaya Sayuran Daun Secara Hidroponik. Jurnal Hortikultur Indonesia. 6(1), 11-19.

Rosliani R. dan Sumarni, N. (2005). Budidaya Tanaman Sayuran dengan Sistem Hidroponik. Balai Penelitian Tanaman Sayuran. Pusat Penelitian Dan 
Pengembangan Hortikultura. Badan Penelitian dan Pengembangan Pertanian. Monografi No. 27.

Sarido, L. dan Junia. (2017). Uji Pertumbuhan Dan Hasil Tanaman Pakcoy (Brassica Rapa L.) Dengan Pemberian Pupuk Organik Cair Pada System Hidroponik. Agrifor, 16(1), 65-74.

Sina, S. Budi, \& Nurjani. (2018). Pertumbuhan dan Hasil Sawi Varietas Pakcoy pada Kombinasi AB-Mix dan Poc Daun Lamtoro Secara Hidroponik, (1). Universitas Tanjungpura. Pontianak. Jurnal Sains Mahasiswa Pertanian. 7(3), 1-10.

Syariefa, E. (2015). My Trubus: Hidroponik Praktis. PT Trubus Swadaya: Jawa Barat.

Telaumbanua, M.M., (2020). Pengaruh Pemberian Pupuk Organik Cair Buah Pepaya Dan Pupuk Ab Mix Terhadap Pertumbuhan Dan Produksi Tanaman Pakcoy (Brassica rapa chinensis L.) Pada Hidroponik Sistem Sumbu. Repository Nomennsen HKBP, Medan. 